We are grateful to Mr. Terry Needham, senior technician of the Blood Flow Laboratory of the Surgical Unit at St. Mary's Hospital, for his expert technical assistance in this study. We would like to thank Geistlich Ltd. for the provision of a tape recorder and W. R. Warner \& Co. for other technical assistance.

REFERENCES

Barnhorst, D. A., and Barner, H. B. (1968). New Engl. f. Med., 278, 264
Franklin, D. L., Schlegel, W. A., and Rushmer, R. F. (1961). Science, 134, 564.

Reich, R. S. (1934). Ann. Surg., 99, 613.

Rushmer, R. F., Baker, D. W., and Stegall, H. F. (1966). F. appl. Physiol., 21, 554.

Strandness, D. E., Schultz, R. D., Sumner, D. S., and Rushmer, R. F. (1967). Amer. F. Surg., 113, 311.

Yao, S. T., Hobbs, J. T., and Irvine, W. T. (1968). Presented to XVII European Cardiovascular Congress, London, 1-3 July, 1968.

\title{
Transient Synovitis of Hip. A Virological Investigation
}

\author{
N. J. BLOCKEY,* M.CH.ORTH., F.R.C.S. ; B. B. PORTER, F.R.C.S.
}

Erit. med. 7., 1968, 4, 557-558

Cummary : Virological studies in 17 children with $\checkmark$ transient synovitis of the hip did not confirm the suggestion that this is caused by a viral infection. Minor trauma is thought to be a more likely cause.

\section{Introduction}

Transient synovitis of the hip is a condition of the joint found in children in the age group 2-12 years. It is characterized by sudden development of pain in the hip or thigh, restricted range of joint movement due to muscle spasm, and limp or loss of ability to bear weight on the affected limb; the radiographic appearance is normal, and after rest in bed for several days the symptoms and signs disappear. The resolution, without specific treatment, of acute signs and symptoms within a matter of days is an essential feature of the diagnosis, and so Perthes's disease, tuberculosis, acute rheumatism, etc., are ruled out.

The condition has been described regularly since 1912, has been given many names, and has had many theories proposed for its cause and pathology. Papers by Adams (1963) and de Valderrama (1963) review the literature adequately. Transient synovitis is the name chosen by most writers, and is accurate and non-committal.

\section{Possible Viral Connexion}

The common slight rise in temperature and sedimentation rate, the normal radiographs, the sterile joint fluid, and nonspecific synovial histology (reported by Adams and de Valderrama), combined with the spontaneous cure without antibiotics and the rarity of significant permanent joint change, suggested to us that this disorder might be the result of a virus infection.

Joint symptoms have been described in at least two virus infections. In mumps (Caranasos and Felker, 1967) it has usually been a migratory arthralgia, though monarticular symptoms have been noted. The hip has been affected only half as frequently as other large joints, and males have been involved more often than females. Rubella synovitis has shown a similar pattern (Chambers and Bywaters, 1963), but here adult females have been the most common sufferers and again the hip has been infrequently involved. Lambert (1968) described three cases having multiple joint involvement resembling rheumatic fever in illness due to Mycoplasma pneumoniae infection. In all these three infections complete resolution has occurred.

* Orthopaedic Surgeon, Royal Hospital jor Sick Children, Glasgow C.4. † Orthopaedic Registrar, Western Infirmary, Glasgow W.1.

\section{Investigation}

For a period of eight months (August 1967 to April 1968) all children who on admission were thought to have transient synovitis of the hip were investigated in co-operation with the Regional Virus Laboratory, Ruchill, Glasgow, as follows:

(a) A sample of venous blood was withdrawn, and about three weeks later a second blood sample was taken. The paired sera from each patient were tested by complement fixation for antibodies to the following infective agents: mumps $S$, mumps $V$, herpes simplex, adenovirus group, parainfluenza I, psittacosis-L.G.V., $\mathrm{Q}$ fever, and $M$. pneumoniae. Rubella haemagglutination-inhibition tests were also performed on the sera.

(b) A specimen of stool was inoculated into rhesus monkey kidney and human amnion tissue for culture to detect enterovirus or adenovirus, and suckling mice were injected to detect Coxsackie virus infection.

Twenty-four children were investigated, but seven were later excluded from this diagnosis of transient synovitis; in three the physical signs could not be confirmed, one developed rheumatoid arthritis, one had tuberculosis of the hip, and two turned out to have staphylococcal joint infection. These seven children acted as controls in the virological inquiry.

\section{Clinical Findings}

The 17 children (eight girls and nine boys) who satisfied the criteria for transient synovitis (see Introduction) had clinical features similar to those so often previously described. All were between 2 and 12 years old. There was no predilection for left or right hip. There was a possible history of trauma in four children, and five had a history of recent infection. Eleven had an axillary temperature of $99^{\circ} \mathrm{F}$. $\left(37.2^{\circ} \mathrm{C}\right.$.) or over and 13 had a sedimentation rate of more than $12 \mathrm{~mm}$. in the first hour (Winstrobe). In all children the hip radiographs were normal.

With rest in bed, and in some cases light traction, all recovered in periods of 3 to 10 days.

\section{Virological Findings}

Serology.-Of the 17 patients who had transient synovitis of the hip 16 had the full serological investigation described, as did six of the seven controls. The complement-fixation findings are shown in the Table. Evidence of current infection as proved by a rising antibody titre was found in only two patients with transient synovitis-one to adenovirus group antigen and one 
to parainfluenza. A rising titre to adenovirus was also obtained in one of the six controls. These viruses are commonly associated with minor respiratory infections and are probably unconnected with the hip condition. High complement fixation titres ( $>64$ ) were obtained most frequently for herpes and adenovirus, both for cases and for controls; these high titres also mirror the high evidence of infection with these agents in the community. Haemagglutination-inhibition tests for rubella showed no rising titres. Antibody was not detected (titres $<10$ ) in 10 cases and three controls; in the remaining patients low haemagglutination-inhibition titres were obtained, indicating past infection.

Complement Fixation Results on Paired Sera from 16 Cases of Transient Synovitis and 6 Controls

\begin{tabular}{|c|c|c|c|c|c|c|}
\hline & \multicolumn{3}{|c|}{ Cases } & \multicolumn{3}{|c|}{ Controls } \\
\hline & $\begin{array}{c}\text { Negative } \\
\text { (Titres } \\
<64)\end{array}$ & $\begin{array}{l}\text { High } \\
\text { Titres } \\
(>64)\end{array}$ & \begin{tabular}{|c|} 
Rising \\
Titres \\
(Fourfold \\
or \\
Greater) \\
\end{tabular} & $\begin{array}{c}\text { Negative } \\
\text { (Titres } \\
<64)\end{array}$ & $\underset{\substack{\text { High } \\
\text { Titres } \\
i(>64)}}{\text {. }}$ & \begin{tabular}{|c|} 
Rising \\
Titres \\
(Fourfolc \\
or \\
Greater) \\
\end{tabular} \\
\hline 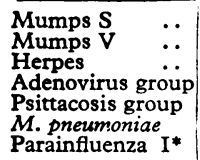 & $\begin{array}{l}16 \\
13 \\
11 \\
10 \\
16 \\
16 \\
13\end{array}$ & $\begin{array}{l}0 \\
3 \\
5 \\
5 \\
0 \\
0 \\
0\end{array}$ & $\begin{array}{l}0 \\
0 \\
0 \\
1 \\
0 \\
0 \\
1\end{array}$ & $\begin{array}{l}6 \\
6 \\
5 \\
4 \\
6 \\
6 \\
6\end{array}$ & $\begin{array}{l}0 \\
0 \\
1 \\
1 \\
0 \\
0 \\
0\end{array}$ & $\begin{array}{l}0 \\
0 \\
0 \\
1 \\
0 \\
0 \\
0\end{array}$ \\
\hline
\end{tabular}

Virus Isolations in Stools.-Stool cultures yielded four different isolations in four of the 17 cases; these were E.C.H.O. 6, E.C.H.O. 19, adenovirus type 3, and Coxsackie A4. These viruses were probably unrelated to the synovitis, as they were common in the community during the period of the study.
The controls also yielded four different isolations-namely, E.C.H.O. 7, E.C.H.O. 19, adenovirus 3, and adenovirus type 5 .

\section{Conclusions}

Virological.-Though it is notoriously difficult to prove a negative, and we cannot exclude the possibility of infection with some agent outside the range of our tests, the virus isolations and serological results do not suggest any connexion between viral infections and transient synovitis of the hip.

Orthopaedic.-Several other workers have drawn a blank in trying to incriminate infection. The theory of causation that attracts us is trauma. In many children the story begins on waking. They cannot walk or bear weight first thing one morning. They have been lying asleep in a fully relaxed state and a minor subluxation of the hip may have occurred which, like "pulled elbow" in a younger age group, gives rise to pain and muscle spasm, has a normal radiograph, and completely recovers in a few days.

We wish to thank Professor N. R. Grist, Dr. Ross, and Dr. Bell of the Regional Virus Laboratory, Ruchill Hospital, Glasgow, for co-operating in this survey, for preparing all the virological work, and for interpretation of the results. We wish to thank Mr. M. G. H. Smith and Mr. D. A. Macpherson for allowing us to study patients under their care.

\section{REFERENCES}

Adams, J. A. (1963). 7. Bone ft Surg., 45B, 471.

Caranasos, G. J., and Felker, J. R. (1967). Arch. intern. Med., 119, 394. Chambers, R. J., and Bywaters, E. G. L. (1963). Ann. rheum. Dis., 22, 263.

Lambert, H. P. (1968). Brit. med. F., 3, 156

de Valderrama, J. A. F. (1963). F. Bone ft Surg., 45B, 462.

\section{Medical Memoranda}

\section{Localized Anticoagulation of the Limbs}

Brit. med. F., 1968, 4, 558-559

Though some clinicians may have used the method of single limb venous anticoagulation to prevent or control deep vein thrombosis, it may be new to others, and attention is therefore drawn to it.

There are occasions when it is very desirable to anticoagulate patients with a high risk of lower limb venous thrombosis, and yet recent surgery or other event precludes this course. It is possible, however, to make use of the rapidity with which the anticoagulant effects of heparin are lost when infused into the circulation, and also of the tendency of any solution injected into the superficial veins on the dorsum of the foot to flow into the intermuscular veins of the leg. Thus by continuous infusion of heparin saline into a dorsal vein of the foot it is possible to anticoagulate venous blood in the deep intermuscular veins of the lower limb from the ankle to the junction of the common iliac veins. By suitably adjusting the dosage infused per hour, clotting-time can be raised significantly in the common femoral vein without simultaneously affecting systemic clotting capacity. Adjustment of the dosage is readily accomplished by sampling blood from this vein and from a vein in an upper limb. It may be expected that there is a heparin concentration gradient from the venous blood in the calf, where the thrombotic risk is great, falling as the common iliac vein is reached, owing to progressive dilution by muscle venous blood.

\section{Illustrative CASE Report}

A woman aged 56 was admitted to hospital for investigation and treatment of worsening intermittent claudication. Her lower lumbar aorta and the upper parts of both common iliac arteries were found to be almost completely occluded by atherosclerotic disease. The aortic bifurcation was resected and a suitable prosthesis was inserted. From this surgery she did well. However, on the third postoperative day she complained of pain and deep tenderness in the left calf. Mild swelling was noted on examination, with a circumferential increase on the left side of $1 \mathrm{~cm}$. $(30 \mathrm{~cm}$. right, $31 \mathrm{~cm}$. left). It was considered that total anticoagulation carried some risk of haemorrhage into the operative site, and it was decided to heparinize the affected limb only, while continuing vigorous physiotherapy.

A needle drip was established in a dorsal vein of the left foot with an adequate length of transfusion tubing to permit free movement of the patient's leg. Heparin at a dosage of $0.5 \mathrm{mg} . / \mathrm{kg}$. body weight/ 6 hours in normal saline was infused. At this dosage both common femoral vein blood and upper limb venous blood had clotting-times within the normal range. Doubling the dosage rate resulted in both femoral and forearm blood developing a clottingtime in excess of 60 minutes. The rate was therefore reduced to $0.75 \mathrm{mg} . / \mathrm{kg}$. body weight $/ 6$ hours ; the clotting-time in the femoral vein was then 15 minutes, compared with eight minutes for blood of the upper limb (normal control: up to nine minutes).

Symptomatically and objectively the patient's leg improved, and when systemic oral anticoagulants were begun eight days after operation all local symptoms and signs had resolved. On the fifth postoperative day a phlebogram was obtained via the heparin infusion needle; good filling of the intermuscular venous system of the leg was obtained, and no abnormality was displayed. The patient left hospital without lower limb symptoms. 